\title{
EXTRAÇÃO E DETERMINAÇÃO DE ATIVIDADE DE PEROXIDASE DO RABANETE, ANALISANDO A INFLUÊNCIA DO ÍON POTÁSSIO.
}

\author{
$\underline{\text { Natalia Bispo Lima }}{ }^{1}$; Heiddy Márquez Alvarez ${ }^{2}$ \\ 1. Bolsista PROBIC/UEFS, Graduanda em Farmácia, Universidade Estadual de Feira de Santana, \\ e-mail: natalialima732@gmail.com \\ 2. Orientador, Departamento Exatas, Universidade Estadual de Feira de Santana, \\ e-mail: marquezheiddy@gmail.com
}

PALAVRAS-CHAVE: Peroxidase; Rabanete; Potássio.

\section{INTRODUÇÃO}

As peroxidases se destacam no cenário biotecnológico por serem encontradas em diversas fontes na natureza, não dependerem de cofatores e atuarem sobre um amplo número de substratos. Podem ser consideradas enzimas bifuncionais, pois catalisam a oxidação de uma ampla variedade de compostos por meio de peróxido de hidrogênio, mas também produzem espécie reativa de oxigênio (MOHAMED et al.,2011)

As peroxidases vegetais tem atraído considerável interesse de pesquisadores, pelo envolvimento dessas enzimas em diversas reações biológicas, como: reações de oxidação, processos de diferenciação celular, crescimento, controle de funções metabólicas e resistências a patógenos (GORTON et al., 1992).

O rabanete (Raphanus sativus L.) é uma Brassicaceae, da mesma família da Brassica oleracea (couve, brócolis, repolho e couve-flor), só que diferente destas a parte consumida é uma raiz tuberosa. Planta de porte reduzido, originária da região do mediterrâneo, produz raízes globulares de variadas colorações, sendo a coloração escarlate-brilhante com polpa branca a mais aceita pelos consumidores (FILGUEIRA, 2008).

O rabanete cresce na camada subsuperficial, dessa forma, o rendimento do rabanete pode ser influenciado diretamente pelas condições químico-físico-hídricas do solo. Considerando este fato o trabalho tem como objetivo conhecer a influência do íon potássio na atividade da peroxidase e no crescimento do rabanete in vitro, tendo em vista que os nutrientes fornecidos e a influência de diversos sais poderiam agir na atividade peroxidásica, na produção e qualidade do rabanete. 


\section{METODOLOGIA}

Germinação das sementes de rabanete: As sementes do rabanete foram colocadas para germinar em meio cultura, Muraschige e Skoog MS que possui sais e vitaminas necessários para o desenvolvimento da planta, esses sais e vitaminas estão divididos em soluções de A a I. As substâncias utilizadas no meio são: nitrato de amônio 82,5 g/L, que compõem a solução A (20 mL da solução para 1L de meio), nitrato de potássio 95 $\mathrm{g} / \mathrm{L}$, que compõe a solução B $(20 \mathrm{~mL}$ da solução para $1 \mathrm{~L}$ de meio), fosfato de potássio 34g/L, ácido bórico 1,24 g/L, molibidato de sódio 0,05g/L , cloreto de cobalto 0,005g/L, iodeto de potássio $0,166 \mathrm{~g} / \mathrm{L}$ que compõe a solução $\mathrm{C}(5 \mathrm{~mL}$ da solução para $1 \mathrm{~L}$ de meio), cloreto de cálcio $8,8 \mathrm{~g} / \mathrm{L}$ compõe a solução $\mathrm{D}$ (50 mL para $1 \mathrm{~L}$ de meio), sulfato de magnésio 74,0 g/L, sulfato de mangânes 4,46 g/L, sulfato de zinco 1,72 g/L, sulfato de cobre $0,005 \mathrm{~g} / \mathrm{L}$ compõe a solução $\mathrm{E}(5 \mathrm{~mL}$ da solução para $1 \mathrm{~L}$ de meio), sulfato ferro $5,57 \mathrm{~g} / \mathrm{L}$, EDTA de sódio $7,45 \mathrm{~g} / \mathrm{L}$ compõe a solução $\mathrm{F}$ (5 mL para $1 \mathrm{~L}$ de meio), tiamina $0,1 \mathrm{~g} / \mathrm{L}$, piridoxina $\mathrm{HCl} 0,05 \mathrm{~g} / \mathrm{L}$, ácido nicotínico $0,05 \mathrm{~g} / \mathrm{L}$ compõe a solução $\mathrm{G}$ (10mL para $1 \mathrm{~L}$ de meio), mio-inositol $(2,0 \mathrm{~g} / \mathrm{L})$ solução $\mathrm{H}(50 \mathrm{~mL}$ para $1 \mathrm{~L}$ de meio), glicina $0,08 \mathrm{~g} / \mathrm{L}$ solução I ( $25 \mathrm{~mL}$ da solução pra $1 \mathrm{~L}$ de meio), no meio também é acrescentado sacarose $30 \mathrm{~g} / \mathrm{L}$ e Agar 7,0 g/L . Neste meio foram adicionadas soluções com diferentes concentrações $(10 \mu \mathrm{M}, 100 \mu \mathrm{M})$ de cloreto de potássio $(\mathrm{KCl})$.

Preparação do meio MS/2: Em um frasco de vidro, colocou-se 1L de água destilada. Em seguida, os sais e vitaminas foram acrescentados. Com a ajuda de um agitador magnético, a sacarose e o ágar foram dissolvidos na solução. Depois que todo o material foi homogeneizado, ajustou-se o $\mathrm{pH}$ da solução para 5,7 e a mesma foi aquecida no forno micro-ondas até a sua fervura. Logo depois, o meio foi distribuído em frascos de vidro (cerca de $60 \mathrm{~mL}$ por frasco), que foram vedados com papel alumínio e papel filme. Por fim, esses frascos foram levados a autoclave, durante 30 minutos.

Desinfestação das sementes: As sementes foram colocadas no etanol a 70\%, durante um minuto. Em seguida, elas foram colocadas no hipoclorito (2\%), por quinze minutos. $\mathrm{O}$ processo acaba após a lavagem das sementes com água destilada.

Inoculação das sementes: Todos os frascos com meio são umidificados com etanol a $70 \%$ antes colocá-los na cabine de fluxo onde as sementes são inoculadas. As pinças são flambadas a cada inoculação de semente. Após a inoculação das sementes os fracos são vedados novamente e levados a sala de crescimento com temperatura controlada em $25^{\circ} \mathrm{C}$. Os rabanetes foram coletados em diferentes períodos do crescimento, 15 dias, 30 dias e 45 dias respectivamente e congelados até a análise.

Extração da enzima e análise da atividade peroxidásica: $O$ tecido vegetal foi lavado, fracionado em porções de $0,1000 \mathrm{~g}$ para obter o extrato bruto. Cada amostra foi macerada no almofariz com $10 \mathrm{~mL}$ de tampão fosfato $(0,05 \mathrm{~mol} / \mathrm{L}), \mathrm{pH}$ 6,5. Posteriormente esse extrato foi filtrado. A atividade enzimática da peroxidase de rabanete (RAP) foi determinada por método colorimétrico, baseado na mudança de absorvência a $470 \mathrm{~nm}$ devido à formação do produto de oxidação do guaiacol, o tetraguaiacol. HIRATA et al., (1998). 


\section{RESULTADOS E/OU DISCUSSÃO}

$\mathrm{Na}$ figura 1 se apresentam os experimentos de germinação realizados no horto florestal,
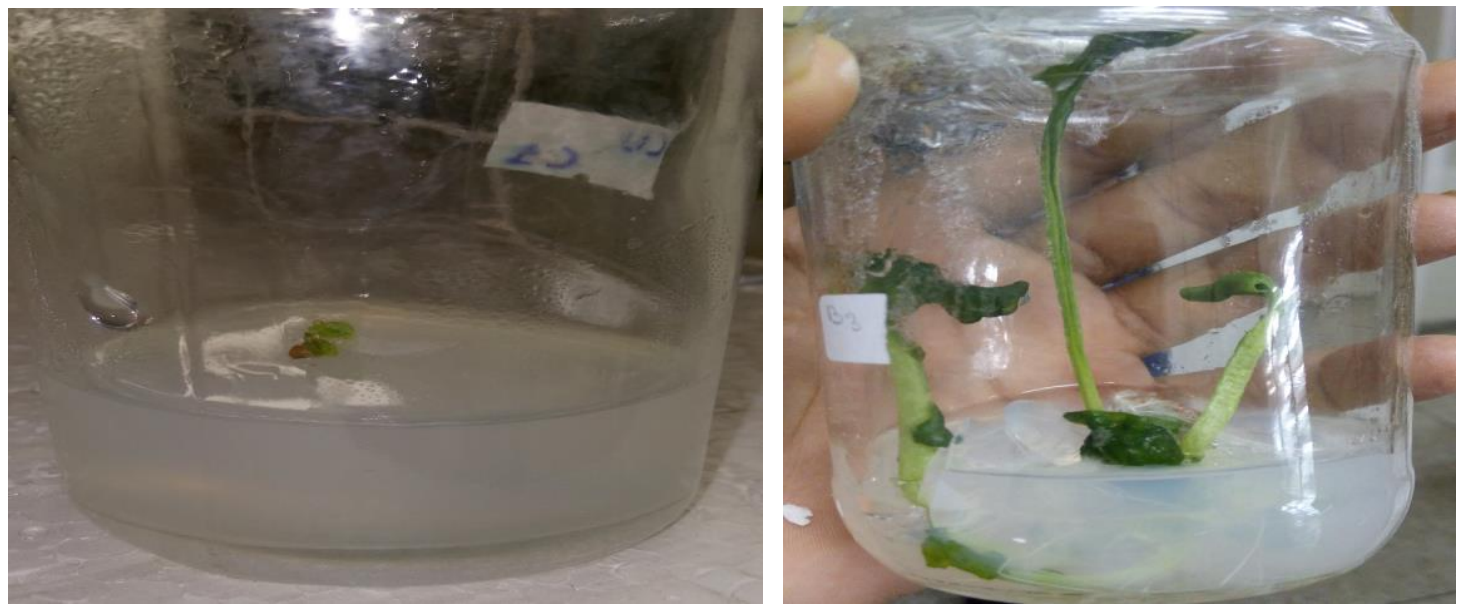

Figura 1. Germinação das sementes de rabanete

As sementes de rabanete (Raphanus sativus L.) começaram a germinar no quarto dia no meio de cultura Muraschige e Skoog (MS). O extrato enzimático do rabanete apresentou maior atividade peroxidasica $(0,49 \mathrm{U} / \mathrm{mL})$ no quadragésimo quinto dia após a germinação no meio de cultura Muraschige e Skoog (MS), que é um meio de cultura que oferece todos os sais e vitaminas necessários ao desenvolvimento da planta.

A adição da solução de cloreto de potássio $(\mathrm{KCl})$ em diferentes concentrações ao meio de cultura MS não influenciou no tempo de germinação das sementes de rabanete, como é descrito na literatura a germinação ocorre aproximadamente em 5 dias e as sementes germinaram dentro desse prazo.. A maior atividade do extrato enzimático do rabanete nestas condições também foi obtido no quadragésimo quinto dia.

A adição da solução de cloreto de potássio $(\mathrm{KCl})$ na concentração de $10 \mu \mathrm{M}$ não interferiu no crescimento do rabanete, que se desenvolveu normalmente, mas a presença do íon $\left(\mathrm{K}^{+}\right)$fez com que houvesse uma pequena redução na atividade enzimática $(0,37$ $\mathrm{U} / \mathrm{mL})$ quando comparado ao rabanete germinado apenas no meio MS $(0,49 \mathrm{U} / \mathrm{mL})$.

$\mathrm{Na}$ figura 2 se apresentam os resultados obtidos da atividade peroxidásica dos extratos de rabanete sob influencia da concentração da solução de cloreto de potássio e o tempo de germinação.

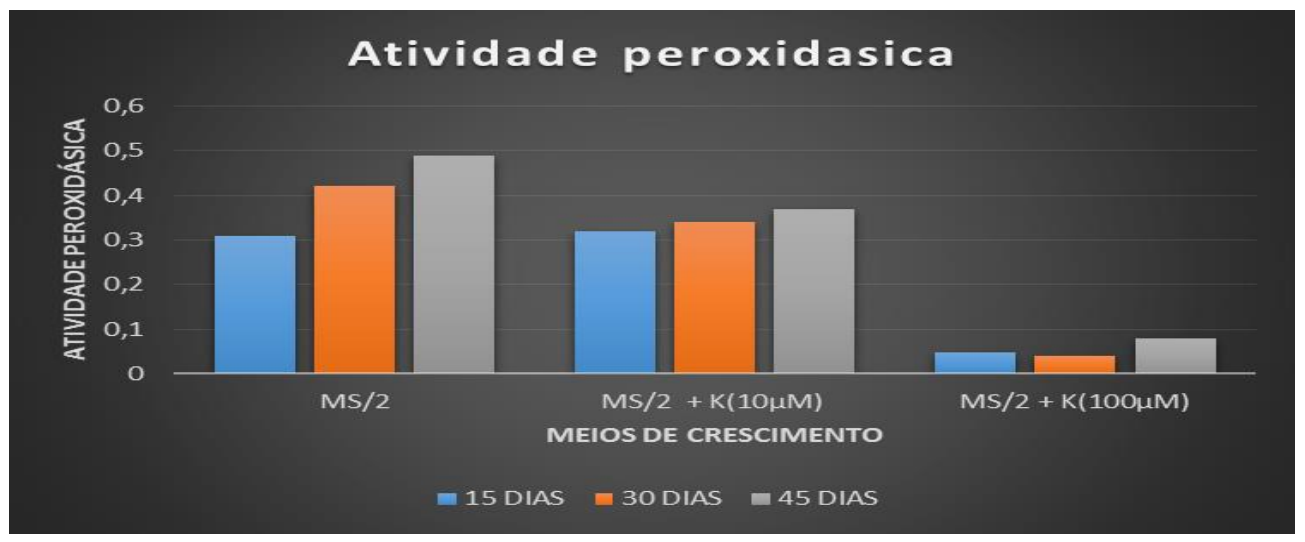


Figura 2. Gráfico que representa a variação da atividade peroxidásica após adição da solução de cloreto de potássio no meio de cultura.

$\mathrm{Na}$ figura 2 pode-se observar que o melhor resultado na atividade peroxidásica foi obtido sem a adição de $\mathrm{KCl}$ e que um aumento na concentração da solução de cloreto potássio $100 \mu \mathrm{M}$ dificultava o desenvolvimento da semente (germinação) e consequientemente a atividade peroxidasica ocasionando uma drástica diminuição da mesma.

\section{CONSIDERAÇÕES FINAIS}

O rabanete apresentou maior atividade peroxidásica $(0,49 \mathrm{U} / \mathrm{ml})$ ao quadragésimo quinto dia após germinação no meio de cultura Muraschige e Skoog. Verificou-se que o cloreto potássio na concentração de $10 \mu \mathrm{M}$ e $100 \mu \mathrm{M}$ causam redução da atividade peroxidasica do rabanete. A adição da solução de cloreto de potássio $(\mathrm{KCl}) \mathrm{em}$ diferentes concentrações ao meio de cultura MS não influencia no tempo de germinação das sementes de rabanete.

\section{REFERÊNCIAS}

FILGUEIRA, F. A. R. Novo manual de olericultura: Agrotecnologia moderna na produção e comercialização de hortaliças. Viçosa, MG: UFV, 2008. 421p.

GORTON, L, PETTERSON-JONSSON, CSOREGI, E., JOHANSSON, K., DONINGUEZ, E.,MARKO-VARGA, G., Amperometric biosensors based on an apparent direct eléctron transfer between electrodes and immobilized peroxidases. Analyst 117,1235-1241, 1992.

HIRATA, T.; IZUMI, S.; OGURA, M.; YAWATA, T. Epoxidation of styrenes with the peroxidase from the culture cells of Nicotianatabacum. Tetrahedron, 54, p. 15993 16003, 1998.

MOHAMED, S.A.; ABULNAJA, K. O.; ADS, A.S.; KHAN, J. A.; KUMOSANI, T.A. Caracterisation of na anionic peroxidase from horseradish cv. Food Chemistry, v. 128, 725-730, 2011. 